\title{
Congressional Fellows at Work, in Seminar
}

\section{Jeffrey Biggs, $A P S A$}

Traditionally, the American Political Science Association's Congressional Fellowship Program has attracted political scientists interested in legislative studies, and it is probably not surprising that many leading congressional scholars are former Congressional Fellows. An unusually qualified group of applicants produced a 1998-99 class of political science Fellows twice as large as and much more intellectually diverse than any previous class. Importantly, all the political scientists have found assignments that allow them to supplement their academic training with "hands-on" experience in the real world.

George Washington University's David Auerswald represents Senator Joe Biden (D-DE) on the Senate Foreign Relations Committee and follows missile defense, arms control, and NATO/U.S. military doctrine-issues he will likely continue to study when he returns to teaching and writing about international relations. Lisa Garcia Bedolla, having recently completed her dissertation at Yale on Latino assimilation, works with Representative Xavier Becerra (D-CA) tracking a wide array of related interests including Central American relief efforts following Hurricane Mitch, immigration, drug certification, banking and financial services, education, and relations among the U.S. and countries in Latin America.

Building upon his dissertation research on shortterm versus long-term forces in U.S. elections, University of California, Irvine's Thomas Brunell started his fellowship year on detail from Representative Dan Miller's (R-FL) office to the Subcommittee on the Census of the House Government Reform and Oversight Committee. Florida International University's Colton Campbell, who has written on congressional ad hoc commissions, changing coalition patterns, and lobbying, works for Florida Democratic Senator Bob Graham studying two key legislative areas that touch virtually every issue before the Congress: the budget and taxes.

Eric Heberlig, who focused on organized labor's grassroots political mobilization for his doctoral work at Ohio State University, has an assignment with Ohio Republican Representative Tom Sawyer. Eric is now working on labor, education, and environmental issues. Ben Highton, whose University of California, Berkeley doctoral dissertation was on the politics of Senate elections, works in Senator Paul Wellstone's (D-MN) office following education, which promises to be one of the key issues before the 106th Congress and in the senatorial elections in 2000.

A Harvard doctoral graduate with an unusual degree of campaign staff and volunteer experience, this year's Steiger Fellow, David Leal, works in John Kerry's (D-MA) office learning more about the governance side of electoral politics. He's also following two of the major legislative issues facing this session: social security and education. The eighth political sci- entist, and one of this year's APSA-MCI fellows, Daniel Lipinski, will be able to augment his Duke dissertation research on communicating images of congressional policy-making to constituents during his service on the staff of the Democratic Policy Committee, which is chaired by Minority Leader Richard Gephardt (D-MO). Lipinski's specific duties include tracking education, crime, and drug issues.

One of the strengths of the APSA Congressional Fellowship Program has always been the diversity of its participants. Classes include political scientists, journalists, government employees specializing in domestic and foreign affairs, Robert Wood Johnson health-policy fellows, and German fellows sponsored by the German Marshall Fund. Joining this group for the first time this year is a Native American Hatfield Fellow.

To prevent Fellows from becoming entrenched in their legislative duties and to ensure they have as full an intellectual experience as possible, biweekly Wilson Seminars are convened during which Fellows share experiences and enlarge their legislative understanding through discussions with outside experts. This year's seminar guests have included Washington Post columnist and national political correspondent, and member of the Congressional Fellowship Program Advisory Committee, David Broder; Prosser Gifford, director of the Library of Congress' Office of Scholarly Programs; Hank Cox, assistant director of the Congressional Budget Office; the Honorable Charles Johnson, House Parliamentarian; and AFL-CIO director of legislative affairs and former Congressional Fellow Peggy Taylor.

Senior Fulbright Scholars visiting the Washington metropolitan area are regularly invited to the Wilson Seminars to provide Fellows an international perspective on the issues they deal with in their congressional assignments. Thus far, the seminar has welcomed Professor Vladimir Zefirov from Russia, who is at Georgetown University's McDonough School of Business; Professor Kuen-Huei from China and the Virginia Military Institute; and visiting Japanese Professors Hideo Otake from Kyoto University and Fumiaki Kubo from Keio University, who are at the University of Maryland's department of government and politics and Georgetown University's department of government, respectively. It would be an understatement to say that the discussion of the AFL-CIO's policy on international trade, including steel imports, was more spirited due to the presence of the Japanese scholars.

Additional upcoming opportunities for the Fellows to collaborate with each other include their organizing and hosting of Canadian Parliamentary Interns for a week's "orientation" to the U.S. Congress, their reciprocal week-long visit to Ottawa, and a visit to the Maryland State House in Annapolis. The Fellows' short stay in Annapolis will be sponsored by the staff of the University of Maryland Baltimore County's Maryland Institute for Policy Analysis and Research. 